\title{
Reform of the Global Financial Architecture: Lessons from Thailand
}

\section{Terry Black and Susan Black}

U S Treasury Secretary Rubin warned of the harm of financial contagion from the Asian crisis and argued that badly flawed financial sectors in a few developing countries and inadequate risk assessment by international creditors and investors can have a significant impact on countries around the globe. He pointed out that a decade ago developing countries raised the majority of their international finance from governments and official sources, with only US $\$ 20$ billion from private sources. However, by 1996 they raised a quarter of a trillion dollars from private sources; equivalent to seven times the amount in official flows. He argued that shifts in these vast capital flows due to policy failure in one country can harm economies throughout the globe. In this paper we analyse the various reasons provided for the Asian financial crisis - with particular emphasis on Thailand and consider the various solutions provided by regulators to reduce the possibility of a recurrence of the crisis.

\section{The Causes of the Financial Crisis}

The financial crisis that engulfed countries such as Thailand, South Korea and Indonesia was largely a problem of bad loans made by the private sector. In June 1997 the Bank of Thailand suspended six finance companies and ten securities firms with combined assets of US\$20 billion, a quarter of the industry total. Almost half the industry's firms had bad loans to the property sector. In August 1997 the Government suspended half of the country's finance firms, which in total owed US $\$ 21$ billion to the Bank of Thailand. The extent of the problem is also highlighted by the associated loans of US $\$ 15$ billion to Thailand made by the International Monetary Fund (IMF).

In any economy not all investments live up to expectations. Typically this means that a small proportion of loans will become bad. However, the Thai crisis was characterised by a large percentage of otherwise good loans becoming bad due to the devaluation of the baht. Prior to the crisis Thailand pursued a policy of fixing the value of its currency (the baht) to the US dollar. When the US dollar appreciated due to a large number of investors judging its relative value to have increased, so too did the baht simply because it was arbitrarily fixed to the US dollar. While the baht remained fixed at the overvalued rate, the potential cost of repaying foreign currency denominated loans was understated. This resulted in

Terry Black is Senior Lecturer in Finance at Queensland University of Technology and Susan Black tutors in Economics at The University of Queensland. 
much investment being profitable only so long as the baht did not devalue. For example, if the managed exchange rate was $15 \mathrm{baht} / \mathrm{US} \$$, a firm requiring $15 \mathrm{~m}$ baht for an investment would have borrowed US\$1m. However, if the baht's market value was actually $20 \mathrm{baht} / \mathrm{US} \$$, then the firm would have borrowed US\$750,000 to obtain the $15 \mathrm{~m}$ baht. Consequently, the overvalued baht caused the firm to borrow US $\$ 250,000$ more than if the baht had been floated. When the overvalued baht became unsustainable and eventually fell to its market value, the firm's US\$1m debt expanded to a $20 \mathrm{~m}$ baht obligation. This will often cause the firm's investment to be no longer profitable.

\section{The exchange rate regime}

A major reason why private overseas lenders and Thai domestic borrowers arranged loans which eventually could not be serviced by the underlying investment was the government-prescribed fixing of the baht to the US dollar. Private lenders were influenced by the expectation that the government would buy baht to support the fixed exchange rate in the event the currency became overvalued. In May 1997, the baht came under strong selling pressures based on deteriorating economic fundamentals. The stock exchange of Thailand fell by over 50 per cent from its peak in February 1996, with foreign selling of banking stocks leading the decline. With the index falling to a six and a half year low, Thailand's stock exchange became the world's worst performer over the previous 17 months. To avert devaluation, the government arranged with the South-East Asian region's central banks to defend the baht, enabling the Thai central bank to borrow cash from other central banks using US Treasury bonds as collateral. Although foreign exchange dealers were unimpressed with the intervention they responded to the increase in Thailand's interest rates by shifting overseas capital into Thailand.

However, the underlying economic fundamentals still pointed to an overvalued currency. Currency dealers, speculating on devaluation, sold baht short, wagering on being able to replace the borrowed currency at lower prices. Thailand's central bank used billions of dollars of its reserves buying baht and introduced different onshore and offshore rates. The two-tiered baht system encouraged arbitrage whereby US dollars were sold for baht onshore around 25.8 and then baht was sold offshore for US dollars for around 22.8 baht. The loss of billions of dollars by the Thai central bank necessitated intervention to force foreign investors to trade in US dollars. This action increased devaluation speculation. ${ }^{1}$

The former Minister for Finance Virabongsa, architect of the 1984 devaluation, said devaluation was necessary to boost exports. The Thailand Development Research Institute also argued that the baht was unrealistically high and needed to

\footnotetext{
${ }^{1}$ Former Australian Reserve Bank Governor Bernie Fraser proposed a two-tier system with differing onshore and offshore rates as a solution to the Asian financial crisis (Wood, Shanahan and Boreham, 1998:1). However, as demonstrated by Thailand's experience, this approach invites investors to take advantage of the arbitrage opportunities and is clearly unsustainable and costly.
} 
be devalued by around 15 per cent. Days after Prime Minister Chavalit stated that the baht would never be devalued, Thailand floated the baht after having used billions of dollars in reserves and high interest rates in a futile attempt to maintain its fixed relationship to the US dollar. The float, resulting in a fall in the value of the baht of 17 per cent, was considered good news by the stock exchange that rose to a five year high. Thai companies with foreign currency denominated debts totalling US $\$ 72$ billion found their debt in baht had increased 17 per cent, causing the majority of the foreign currency denominated loans to become uneconomic and firms to become insolvent.

With a floating exchange rate there is a risk of the rate deteriorating against the borrower. The borrower can incur this risk or protect against it by, for example, a forward exchange contract to 'lock in' a repayment rate. Either way, the cost of borrowing would have been higher than under the overvalued fixed exchange rate, which misled borrowers into believing there was no exchange rate risk. An important lesson from the Asian financial crisis is that foreign exchange risk exists regardless of the exchange rate regime. Had borrowers realistically taken into account the ultimate devaluation of the baht and the consequent increased cost of borrowing overseas, much investment would have been recognised as unprofitable and hence Thailand's bad loan problem would have been substantially reduced.

Signs that the baht was overvalued were evident when export growth fell from 23.6 per cent in 1995 to zero in 1996. Further, the overvalued baht encouraged imports, with the Prime Minister Chavalit arguing that Thais had been overconsuming. The declining exports and rising imports resulted in a current account deficit. Initially this was financed by capital inflow resulting in capital account surpluses. When markets considered the baht to be overvalued, a flight of capital put the capital account into deficit. Faced with both current and capital account deficits, foreign exchange reserves commenced to run down rapidly. High interest rates were utilised to stem the loss of capital but devaluation was inevitable. The deterioration in the current account provided the government with evidence that the baht was overvalued, but it stubbornly defended the exchange rate by running down its foreign reserves. In May 1997 reserves dropped by US\$33.3 billion. Maintenance of the overvalued baht encouraged further foreign currency loans which were to prove bad when the currency ultimately devalued.

Feldstein (1998:23) referring to Thailand, Indonesia, Malaysia and the Philippines argued:

All of these countries clearly need to shrink their current account deficits by increasing exports and reducing imports. That in turn requires reductions in public and private consumption and investment. The proper remedy is a variant of the traditional IMF medicine tailored specifically to each country - some combination of reduced government spending, higher taxes and tighter credit. 
This approach is a recipe for recession and provides no assurance that the problem will be solved without adjustments to government spending, taxation and credit. In contrast, the alternative of floating the currency directly targets the problem arising from the overvalued currency. Had Thailand not fixed the baht to the US dollar it would not have had a current account problem - any deficit would have been offset by a capital account surplus and the balance of payments would have been continually in balance without affecting foreign currency reserves.

\section{Moral hazard}

Financial regulators have argued that inadequate risk assessment by international lenders was a central cause of the crisis. However, the risk assessments performed were a rational response to the moral hazard problem, whereby sovereign government guarantees and the strong expectation of IMF bailouts resulted in lenders regarding the risk of bad loans as negligible. In combination, these interventions virtually eliminated perceived default risk and hence removed lenders' incentives to assess and monitor loans. Consequently, this so-called market failure of inadequate risk assessment was actually due to government intervention.

While the Asian crisis is characterised by bad loans by the private sector, this is a misattribution due to the existence of extensive government guarantees. In fact, the guarantees effectively converted the loans into Government debt. The failure of the Bangkok Bank of Commerce heralded the beginning of the end. It was rescued by the Bank of Thailand and was kept open until the IMF package in August 1997. Bad debts in this institution exceeded 85 per cent of its total lending. The involvement of the Government in Thailand's banking industry resulted in banks making loans for political reasons rather than on a commercially prudent basis. Banks operated on the understanding that loans made consistent with the government's wishes would be guaranteed in the event they became uneconomic. This expectation led to a self-fulfilling prophecy and the greater the involvement of the government the greater the domestic moral hazard problem.

The Asian financial crisis did not occur in all countries simultaneously. Rather, it was a country by country phenomenon with Thailand the first to suffer and be bailed out. IMF involvement in the Thai crisis resulted in the strengthening of expectations of further IMF bailouts. Consequently, the IMF created a strong contagion effect whereby it greatly increased the expectation that the creditors of other countries would also be rescued. This occurred with South Korea, Indonesia and more recently Russia and Brazil.

Past IMF behaviour in Mexico created a moral hazard problem whereby lenders to Thailand were not motivated to assess and monitor loans thoroughly because of expectations that the IMF would effectively be taking over the loans in the event they became non-performing. In the absence of expectations of IMF bailouts, lenders would have been faced with the full consequences of their lending decisions. This would have caused lenders to investigate investment projects thoroughly to ensure that they were able fully to service loans. Had the IMF not created the expectation 
of Thai lenders being bailed out, the loan problem would have been constrained to borrowers and lenders. Both parties would have had strong incentives to finance only projects considered to be profitable.

In the absence of IMF involvement, the lender takes charge of the underlying security when a loan becomes non-performing, and can either operate the asset or dispose of it. Consequently the market-determined outcome results in the asset passing into the hands of new owners and managers who are more efficient than the borrower. However, IMF bailouts leave the borrower with the asset and the absence of bearing costs from poor investment decisions results in a continuation of this moral hazard behaviour.

The existence of the IMF, and in particular its bailout of Mexico, encouraged most Thai creditors to push the crisis to the point where the IMF entered the country and directly or indirectly bailed out debt-holders. This resulted in a mass exodus of capital from Thailand in a very short time. The action of many foreign banks mirrored this short-term imperative by ensuring that the IMF was a party to negotiations. With the IMF becoming a player, the incentive existed for foreign lenders to withdraw funds and cut all existing credit lines in order to hasten IMF involvement and protect creditors' downside risk. This was a rational response for each creditor because of the prospects of a larger pay out with less risk from the IMF becoming involved. In order to ensure the IMF bailout occurred, most creditors caused a massive and sudden capital outflow.

\section{Aftermath of the Crisis}

In the aftermath of the Asian financial crisis, consensus exists amongst financial regulators that, had the sudden capital outflow been orderly and not sudden, the crisis would have been greatly reduced and may even have been avoided. According to IMF figures, Thailand, South Korea, the Philippines and Indonesia combined had net inflows of short-term international capital of US\$14 billion in the first nine months of 1997 compared with a net outflow of US\$33 billion in the last three months of 1997. This massive capital outflow was in response to the market's view that the currencies were overvalued. The inflow in the early part of 1997 was largely due to high domestic interest rates.

It is possible that previous IMF bailouts motivated international lenders to precipitate the IMF involvement in Thailand by a mass exodus of capital. In the absence of the IMF, creditors would have made extrinsic decisions on whether to foreclose or extend a loan or to pursue other options. There would have been a wide variety of different outcomes. In a normal workout, institutions assess the underlying solvency of a business and may extend credit to allow an orderly disposal of assets.

Regulators regard the capital flight as driven by 'herd mentality' instead of a rational assessment that the currency was overvalued as indicated by economic fundamentals. The rational view indicates that even if the capital flight had been 
constrained by regulators, the overvalued baht still needed to devalue as occurred and hence the Asian crisis would not have been avoided.

The inherent nature of fixed exchange rates provides incentives for lenders to identify the risk of imminent devaluation to ensure they can withdraw capital while the central bank still has reserves. Thus, even if regulatory constraints had forced a slow and orderly withdrawal of capital, the baht would still have devalued by the same amount as occurred.

\section{Restrictions on capital flows}

Calls for reform of the world's financial system have focused on capital flow restrictions to avoid contagion. The Oxford Dictionary defines 'contagion' as the communication of an infectious disease. Describing the Asian financial crisis as contagion implies that Thailand sneezed, infecting South Korea, Indonesia, the Philippines, Malaysia and now Russia and Brazil with colds. This classification suggests that a financial crisis in one country can be spread to otherwise healthy countries including Australia and the US.

However, the recent financial difficulties were caused by inherently unhealthy economic systems in the form of fixed exchange rates. Eventually, fixed exchange rates will be in disequilibrium, in this case they became overvalued. Consequently, a capital flight occurred when the economic fundamentals indicated there would be a devaluation. Contagion occurred when the fixed exchange rates of other exportcompeting Asian countries also became overvalued, following the devaluation of the baht. There is a widespread view by regulators that contagion is an irrational force which causes fear to overrule reason. However, hedge funds and other investors were extremely rational in recognising overvalued exchange rates.

Healthy countries have immunity from contagion in the form of floating exchange rates which adjust rapidly in response to new information. Rather it is the fixed exchange rate regimes which are prone to contagion. Restructuring the international financial architecture incorrectly addresses the symptoms rather than the cause of the crisis. A more appropriate solution would be to target the cause directly by allowing market forces to determine currency values.

Calls for capital controls are misdirected as they too address the symptoms and not the underlying cause of the Asian crisis. Blaming the hedge funds is akin to 'shooting the messenger'. By seeking out high interest rates, hedge funds serve a useful purpose in supplying overseas currency and reducing domestic interest rates, thereby restoring fixed exchange rates to market equilibrium. Restrictions on hedge funds will at best delay the process and at worst will enable interest rates to remain higher than necessary. Capital controls that impede the world-wide mobility of capital result in continuing high domestic interest rates in countries that implement them. Consequently, investment and living standards would be curtailed. In contrast, the absence of capital controls allows funds to flow to the areas generating the highest return. Competition will then drive interest rates down, generating 
additional investment. Instead of attempting to restrict hedge funds, the real problem needs to be addressed - the fixing of the exchange rate to the US dollar.

There is a view that hedge funds may reduce liquidity by particular plays in financial markets and exaggerate, rather than contain, price movements. However, the Asian illiquidity problems were due to an overvalued fixed exchange rate, and the hedge funds were merely the vehicle that took advantage of poor government policy. The demand for the overpriced domestic currency is less than supply, resulting in a shortage of foreign currency. In particular, in South Korea, convertibility ceased, with foreign exchange markets closing within ten minutes of opening for five days straight, resulting in a total unavailability of foreign exchange.

While the IMF/World Bank meeting in April 1998 did not support international capital controls, they did approve national controls, providing they were called 'prudential safeguards'. Michael Mussa, Chief Economist with the IMF, said that it is not a capital control if Thailand establishes prudential regulation to ensure financial institutions are not over-exposed. However, financial institutions only became over-exposed to short-term foreign debt when the fixed exchange rate devalued and this over-exposure would not have occurred if the currency had been floated several years earlier.

Over time it is inevitable for fixed exchange rates to result in disequilibrium and hence speculation of devaluation. Rather than attempts to restrict hedge funds, the solution is to allow exchange rates to float freely. This would largely avoid the 'bad loan problem' that resulted from the adoption of fixed exchange rates and were revealed following the 17 per cent devaluation of the baht in July 1997. It would also eliminate opportunities for hedge funds and may result in them losing their 'bad boy' image.

\section{IMF loan effects}

The consequence of the IMF bailing out foreign lenders is that the burden of repaying these loans has been shifted from Thai business borrowers to Thai taxpayers. The IMF loans are clearly an adverse result for Thai citizens who would have no loan repayment tax burden if the debt remained with the borrowers who would then continue to be liable to foreign lenders.

The IMF bailout also acts as a disincentive for Asian countries to reform their pervasive crony capitalism and corruption. Although the IMF loans are conditional on fiscally-stringent reductions of budget deficits and some opening up of the economy, it is likely that Asian governments will at best do only the minimum necessary to comply with IMF requirements. If IMF funds were not available, then Asian governments would be responsible for putting their own houses in order rather than shifting blame to foreign lenders. Allowing their currencies to float freely is a major step to avoiding loan problems. Changes in credit risk perceptions would then be reflected in the value of the currency and the higher cost of borrowing would act as a deterrent to uneconomic borrowing. 
At the behest of the IMF, Thai interest rates have remained high to stabilise the baht. No doubt IMF officials approved the increase in the baht's value from a low of 56 to the US dollar to around 40 . However, the result of the crippling interest rates was a continuing contraction of the economy with the January 1998 production index falling 16.4 per cent and exports falling by 7.9 per cent. The IMF cure for Thailand and other Asian countries is likely to be worse than the market solution negotiated between foreign creditors and Thai borrowers. The major winners from the IMF interference are foreign lenders. The major losers from the IMF 'solution' are taxpayers. Transferring private debt to government debt forces the loan obligations on to innocent bystanders - the country's citizens. They did not share in the past high profits but were encumbered with the resultant losses. When the IMF loans start to fall due, taxpayers can expect their tax burden to increase substantially.

\section{Increased disclosure}

A different proposal for reform of the world's financial architecture was suggested by the US Treasury Secretary Rubin, just prior to the 1998 spring meetings of the World Bank, the IMF, the G7 finance ministers and the new group, the G22. Both Rubin and the G22 have acknowledged that the most powerful enforcement mechanism in the world with respect to sound policy is the market. Rubin's plan focused on the provision of better information on all of the world's economies and their exposure to global capital markets, and includes minimum global standards for issues such as bankruptcy regimes, banking supervision, corporate governance and accountancy rules. These standards would not be compulsory. Rubin's premise was that, if markets are well informed, they will make rational decisions.

The fact that he considered the plan necessary implies a belief that markets were not well informed and that his plan would improve the situation. However, competition between numerous market players, together with the potentially large gains from obtaining information before rivals, provide the necessary incentives for markets to become informed. The Efficient Market Hypothesis (EMH) predicts that publicly-available information is rapidly acted upon so that no abnormal gains are obtainable from trading on the information (Watts and Zimmerman, 1986:17):

Competition in the classical certainty world of price theory (microeconomics) drives economic profits to zero. Economic profits are calculated after deducting a market rate of return (interest) on capital. The EMH is essentially the extension of that zero profits equilibrium condition to the dynamic behaviour of prices in competitive markets under uncertainty. 
This theory was empirically tested by Meek (1983:400):

A frequent theme in the international accounting literature is that the differences in accounting principles used by the world's multinational corporations to report their financial results act as an impediment to the optimal allocation of worldwide resources. The contention rests on the idea that a lack of comparability in financial reporting hinders decision-making by investors and other financial statement users. .... The US securities market impounds the information contained in foreign companies' earnings, which may not be based on US GAAP. Furthermore, the markets' reaction is comparable to its reaction to net income numbers produced by US firms using US GAAP. .... US investors can apparently overcome a lack of comparability.

Since private information can earn the holder economic profits, investors have strong incentives to seek out information and trade on it. Consequently, competition ensures that investors are well informed. It is questionable whether the Rubin plan will make markets any more informed. Even if it does, the fact that markets have not previously obtained the information indicates that they judged that the costs of becoming better informed exceeded the benefits. To the extent the IMF or other regulatory bodies require additional disclosure beyond that deemed necessary by markets, it is uneconomic. In any event the financial crisis was not due to a lack of information but rather the fixing of exchange rates to the US dollar. Accordingly the Rubin plan is irrelevant.

\section{Conclusion}

There have been widespread calls for the reform of the world's financial architecture. The major rationale is contagion. However, contagion only occurs under 'unhealthy' fixed exchange rates, and the adoption of 'healthy' floating exchange rates provides immunity against it. Thailand's fixed exchange rate concealed the foreign currency risk, with the inevitable devaluation of the baht causing bad loans to arise. The baht's devaluation resulted in the mis-alignment of the fixed exchange rates of its Asian neighbours. The consequent devaluation of other Asian currencies revealed their own financial problem of bad loans.

In addition to overvalued fixed exchange rates understating foreign currencydenominated debt and thereby encouraging excessive borrowing, sovereign guarantees greatly reduced the usual market incentives to ensure the viability of loans. Further, the involvement of the government in Thailand's banking industry resulted in banks making loans for political purposes rather than on a commerciallyprudent basis.

In the aftermath of the Asian financial crisis, consensus exists amongst financial regulators that, had the sudden capital outflow been slowed down, the effects of the crisis would have been greatly reduced. The sudden capital outflow was not a 
normal market response, but was an artifact of past behaviour of the IMF, notably the Mexican/Latin America experience. In a normal workout there would have been a smaller capital outflow spread over a longer period compared with under the IMF bailout. However, irrespective of whether the capital flight was sudden and large, or slow and small, the overvalued baht would still have devalued as occurred.

Other proposals for the reform of the world's financial system include greater disclosure and capital controls. However, they are unnecessary and harmful, respectively, and they fail to address the problem by focusing on the symptoms. It is suggested that if the Asian countries had adopted floating exchange rates, the Asian financial crisis would have been reduced.

\section{References}

Crispin, S. (1998), 'Without a Net', Far Eastern Economic Review, July 9, p. 69.

Feldstein, M. (1998), 'Refocusing the IMF', Foreign Affairs, March/April, pp. 20-33.

Meek, G. (1983), 'US Securities Market Responses to Alternative Earnings Disclosures of Non-US Multinational Corporations', The Accounting Review April:394-401.

Watts, R. and J. Zimmerman (1986), Positive Accounting Theory, Prentice-Hall International, Englewood Cliffs, New Jersey.

Wood, A., D. Shanahan and T. Boreham (1998), 'Radical Rescue for Rupiah', The Australian, March 11, p. 1.

Thanks are extended to the two anonymous referees for their helpful comments. 